УДК 398.32

ББК 82.3

\title{
ЛИТЕРАТУРНЫЕ ИСТОЧНИКИ СКАЗОК ВЕПСА Ф. С. СМИРНОВА (1863-1938)
}

\author{
АНАСТАСИЯ СЕРГЕЕВНА ЛЫЗЛОВА \\ (Институт языка, литературы и истории Карельского научного центра \\ РАН: Российская Федерация, Республика Карелия, 185910, г. Петрозаводск, \\ ул. Пушкинская, д. 11)
}

\begin{abstract}
Аннотация. Статья посвящена репертуару вепсского сказочника Филиппа Семеновича Смирнова (1863-1938), тексты которого были забиксированы в 1935-1936 г2. преимущественно на русском языке, и позднее составили отдельную архивную коллекиию русскоязычного фольклорного фонда Научного архива Карельского научного иентра РАН. Основная часть сказок вошла в опубликованный в 1941 г. в Петрозаводске сборник «Вепсские сказки», подготовленный к изданию Г. Е. Власьевым. Ф. С. Смирнов, будучи грамотным человеком, пополнял свой репертуар за счет различных титературных произведений: многие тексты, записанные от него, восходят к сказкам А. С. Пушкина, П. П. Ершова, Х. К. Андерсена, лубочным сказкам, а также переводным рыиарским романам и повестям XVIII в.

Ключевые слова: вепсский сказочник, Ф. С. Смирнов, сборник «Вепсские сказки», литературные источники, лубочные сказки.

Статья подготовлена в рамках выполнения госзадания КарНЦ РАН "Фольклорные традиции и рукописная книжность Европейского Севера: источниковедение, текстология, поэтика, этнограбический контекст", номер госрегистраиии AAAA-A18-118030190094-6.
\end{abstract}

Дата поступления статьи: 23 июля 2019 г.

Дата публикации: 10 декабря 2019 г.

Для цитирования: Льзлова А.С. Литературные источники сказок вепса Ф. С. Смирнова (1863-1938) // Традиционная культура. 2019. Т. 20. № 5. С. 196-206.

DOI: $10.26158 /$ TK.2019.20.5.017

Создание в 1930 г. в Петрозаводске Карельского научно-исследовательского института (КНИИ, ныне Институт языка, литературы и истории КарНЦ РАН - ИЯЛИ КарНЦ РАН) способствовало собиранию и изучению устного народного творчества. При этом наряду с записью произведений русского фольклора сотрудники института вели активную деятельность по фиксации фольклора прибалтийско-финских народов, проживающих на территории Карелии и сопредельных областей (Вологодской, Ленинградской, Мурманской).

К числу таких народов относятся вепсы, которые в прошлом были обширно расселены в так называемом Межозерье, т. е. в пространстве между тремя крупнейшими озерами: Онежским, Ладожским и Белым. В настоящее время вепсы проживают в восточной части Межозерья, входящей одновременно в состав Республики Карелия, Вологодской и Ленинградской областей. 
В 1935-1938 гг. сотрудники Карельского НИИ совершили ряд экспедиций в вепсские поселения Карелии и Ленинградской области. Во время этих выездов были зафиксированы произведения различных фольклорных жанров (песни, частушки, сказки, загадки, заговоры, пословицы и поговорки, причитания).

Наибольшее количество сказок - свыше 50 - удалось записать в 1936 г. в д. Вонозеро Оятского района Ленинградской области от 73-летнего вепса Филиппа Семеновича Смирнова [Подробнее о нем: Лызлова 2009]. Практически все тексты были рассказаны и записаны на русском языке; лишь семь из них представляют собой короткие сказки-анекдоты на вепсском языке, содержащие нецензурные выражения. Собранные от Ф. С. Смирнова сказки составили 115-ю коллекцию русского фонда Научного архива КарНЦ РАН (НА КарНЦ РАН).

Такого количества сказок в дальнейшем не удавалось записать ни от одного вепса. Об этом свидетельствует сводная «Опись текстов вепсских сказок из коллекций Архива КарНЦ РАН», представленная в сборнике, подготовленном сотрудниками ИЯЛИ КарНЦ РАН Н. Ф. Онегиной и М. И. Зайцевой [ВНС 1996, 201-217]. Вместе с тем репертуар Ф. С. Смирнова не учтен в указанной описи. Обусловлено данное обстоятельство лишь тем, что записи были сделаны на русском языке.

На основе полученных материалов собиратель Г. Е. Власьев позднее подготовил к печати сборник «Вепсские сказки», который вышел в свет в 1941 г. Несмотря на то что тираж издания обозначен в размеpe 10 тысяч единиц, в библиотеках г. Петрозаводска его обнаружить не удалось. Судя по тому, что книга была подписана к печати 14 апреля 1941 г. (практически перед самой войной), тираж, скорее всего, был опубликован не полностью или же утрачен во время войны. Один экземпляр книги долгое время хранился в личном архиве основателя Шелтозерского вепсского этнографического музея Р. П. Лонина, сейчас, после его смерти, издание принадлежит к числу экспонатов музея [Об этом подробно: Лызлова 2011].

Сборник представляет собой книгу обычного формата, насчитывающую 260 страниц. В него вошли 39 сказок из репертуара Ф. С. Смирнова. По-видимому, остальные тексты не были включены в издание из-за их содержания. Большинство этих сказок помечены в коллекции словами «нецензурная», «срамная». Эта антология имеет, как нам представляется, достаточно высокий для времени своего выхода научный уровень, о чем свидетельствует сопровождающий аппарат (вступительная статья, комментарии и словарь). Быть может, его название не совсем точно соответствует внутреннему наполнению, так как включает в себя репертуар одного сказочника. В силу ряда обстоятельств заглавие сборника пришлось менять на этапе подготовки: «Сказки вепса Смирнова» превратились в «Вепсские сказки», поскольку его имя не должно было фигурировать на обложке из-за неблагополучной биографии.

Более чем две трети из включенных в сборник текстов являются сказками волшебными на широко распространенные, прежде всего в русской сказочной традиции, сюжеты. Таковы, например, «Сивкабурка», «Омелюшка-дурачок», «Иван-царевич и Жар-птица», «Иванушко-медвежьи ушки» и др. Все они присутствуют в так называемых лубочных изданиях, выходивших огромными тиражами на протяжении XIX столетия, авторы которых брали за основу популярные фольклорно-сказочные сюжеты и по-своему их обрабатывали, усложняли, придумывая замысловатые контаминации. Публикация таких произведений была прекращена в 1918 г. О подобной литературе писала в своих работах К. Е. Корепова [Корепова 2012]. Что касается Ф. С. Смирнова, то он, будучи грамотным человеком, имел большую домашнюю библиотеку, в которой значительное место занимали лубочные произведения, оказавшие влияние на его репертуар.

Сказка Ф. С. Смирнова «Кощуй Бессмертный» представляет собой контаминацию нескольких сюжетных типов: 552A Животные-зятья; 4002 Царь-девица; 4001 Муж ищет исчезнувшую или похищенную жену [СУС 1979]. Впервые такая комбинация встречается в «Сказке второй о Иване-царевиче», помещенной в сборнике «Сказки русские, содержащие в себе 10 различных сказок. Собраны и изданы Петром Тимофеевым», опубликованном в Москве в 1787 г. Началом текста служит сюжетный тип о животных-зятьях, 
в котором три сестры героя становятся женами трех орнитоморфных персонажей: «<..> сей незнакомый, превратясь опять в Орла и подхватя свою невесту (старшую сестру. - А. Л.), в ту ж минуту полетел с нею из государства»; «<...> сей незнакомый, подхватя свою невесту (среднюю сестру. - А. Л.) и превратясь опять в Ворона, полетел из государства, а царевич остался во дворце и с меньшею сестрою проливать слезы»; «<...> как скоро незнакомый услышал, что царевич согласен, то, превратясь опять в Сокола и подхватя свою невесту (младшую сестру. - А. Л.), полетел с ней из государства и оставил царевича проливать слезы о своих сестрах» [Тимофеев 2001, 245, 246, 247]. У Смирнова в роли похитителей сестер Ивана-царевича тоже выступают три орнитоморфных персонажа, это выясняется, когда брат поочередно оказывается в гостях у каждой из сестер: «Помнишь, мы гуляли в саду, нам показалось облачко. Это не облачко было, а мой муж, Черный ворон под названием. <...> Он меня похитил, и мы повенчались»; «Это не облачко было, а мой муж, Сизый голубь под названием»; «Это не облако было, а мой муж, Ясный сокол под названием» [ВС 1941, 32, 33, 34]. Далее при помощи подаренных зятьями чудесных предметов Иван-царевич женится на Елене Прекрасной и, освободив находящегося у нее в плену Кощуя Бессмертного, погибает. Черный ворон, Сизый голубь и Ясный сокол оживляют Ивана-царевича, используя живую и мертвую воду: «Вот они приложили отрубленную голову к шее, спрыснули мертвой водой - она срослась. Потом спрыснули живой водой. Он и скочил: “- $\mathrm{Ax}$, как я долго проспал!” " [ВС 1941, 37]. В сказке из сборника П. Тимофеева женой Ивана-царевича становится Марья Маревна, а освобожденным пленником оказывается змей - «король Еракский», который разрубает героя на мелкие части. Оживляют его Орел, Сокол и Ворон: «... начали они складывать изрубленное тело Ивана-царевича, и как собрали все части, то спрыснули мертвою водою, и все тело срослось, потом спрыснули живою водою, то Иван-царевич встал, как от сна пробудился, и говорил им: “Ах, любезные зятья! Как долго я спал!” „ [Тимофеев 2001, 255-256]. Решив вернуть жену, герой увозит ее, а позднее вступает в схватку с настигнувшим беглецов Еракским королем или Кощуем Бессмертным, используя одинаковое оружие:

\begin{tabular}{|l|l|}
\hline «Тогда Еракского ко- & «Кощуй-бессмерт- \\
роля конь побежал & ный бросился с шаш- \\
и догнал в короткое & кой на него, махнул, \\
время Ивана-царе- & он поставил свою \\
вича. А как увидел & шашку. Как только \\
царевич Еракского & коснулась Кощуева \\
короля, то, вынув & шашка его шашки, и \\
свой меч, изрубил & сразу его (Кощуева) \\
его в мелкие части, & шашка сделалась как \\
а коня его взял и по- & оловянная. И Кощуй \\
садил на него Марью & сразу ослабел. \\
Маревну. & Иван-царевич сразу \\
И так оба поехали в & отрубил ему голову, \\
Кипрское государ- & и остался бездыхан- \\
ство» & ный труп. Разрубили \\
[Тимофеев 2001, & тело Кощуево на ку- \\
260-261]. & ски, сожгли на огне \\
& и пепел по ветру \\
пустили. И поехали \\
домой» [ВС 1941, 38].
\end{tabular}

По замечанию Г. Е. Власьева, «...поиски смерти Кощуя здесь упрощены и не развернуты в специальный сюжет» [BC $1941,254]$, в отличие от другой сказки Смирнова - «Про Добромысла и про сына Ивана-богатыря», изложение которой, «по-видимому, указывает на связь с книжной традицией (характерно самое имя Добромысла, а также замена лягушки “старушкой”; из книги, вероятно, идет и имя волшебника Карачуна)» [ВС 1941, 256]. В основе текста лежит сюжетный тип «Царевна-лягушка», но в болоте, куда улетела стрела, герой находит не лягушку, а старушку: «И вот попал он в топкое болото. <..> Вдруг перед ним стоит стараяпрестарая старушка, морщиватое лицо» [BC 1941, 125]. Внешность старушка могла менять с помощью кольца, «но Иванубогатырю, когда она легла спать, хочется показать всем ее красоту. Когда она уснула, он снял с нее перстень и побежал, бросил в море. В это время злой Карачун воспользовался своим волшебством, так как не прошел двухгодичный срок, он похитил ее» [ВС 1941, 130]. Отправившись на поиски, герой трижды оказывается в избушке на курьей ножке, на веретяной пятке, в каждой из которых живет старуха, туда каждый раз прилетает его жена, превратившись в разных птиц (в черного ворона, сизого голубя, ясного сокола), но 
Иван-богатырь не справляется с заданием удержать ее в течение определенного времени. Герой, по совету последней старухи, идет за тридевять земель, в тридесятое царство к их старшему брату и встречает по пути стаю голубей, затем стадо слонов, кормит их. Далее он приходит к реке, где «человек стоит на камне, моет руку, в крови рука» [ВС 1941, 134]; Иван-богатырь перевязывает руку носовым платком, а в благодарность человек приводит его в мастерскую: «там все мастерства на свете. Каждый на своем ремесле работает, и все молчат - никто ничего не говорит» [ВС $1941,134]$. В царстве Карачуна ему приходится выполнять три сложные задачи, с которыми он справляется при помощи встреченных ранее птиц, животных и мастеров: 1) голуби распределяют смешанные семена (рожь, льняное семя, клеверное семя) по трем грудам; 2) слоны выливают воду из озера и вычищают грязь со дна; 3 ) мастера строят за одну ночь собор, с колоколами и иконостасом. Карачун повторно исчезает вместе с женой Ивана-богатыря, и тот, узнав, где находится смерть похитителя, отправляется искать заветное яйцо.

Появление подобной чрезвычайно сложной сюжетной контаминации, включающей использование необычных мотивов и эпизодов, связано со «Сказкой о Иване-богатыре, о прекрасной супруге его Светлане и о злом волшебнике Карачуне», неоднократно издававшейся в России с середины 50-х годов ХІХ в. и до 1918 г. Впервые сказка с таким названием была опубликована анонимно в 1856 г., в переиздании 1859 г. был указан автор текста: оказалось, что его сочинил писатель, активно участвовавший в создании лубочных произведений Ф. М. Исаев, который впоследствии несколько раз ее перерабатывал. В 1895 г. появилась редакция той же сказки, сочиненная И. С. Ивиным, печатавшимся под псевдонимом «И. Кассиров». Этот автор оставил почти без изменения конечный исаевский вариант, усложнив его сюжетной линией, связанной с Карачуном. Согласно исследованию, проведенному К. Е. Кореповой, «Сказка о Иване-богатыре, о прекрасной супруге его Светлане и о злом волшебнике Карачуне» была представлена в шести неоднократно переиздававшихся лубочных редакциях. «Многочисленные публикации сказки оказали сильнейшее влияние на устную традицию» [Корепова 2012, 175], текст Ф. С. Смирнова демонстрирует пример такого воздействия, в нем сохраняется сложная композиция, объединяющая несколько сюжетных типов, зафиксированных в указателе под номерами: 402 Царевна-лягушка, 4001 Муж ищет исчезнувшую или похищенную жену, 554 Благодарные животные, 3022 Смерть Кощея в яйце. Более подробно о влиянии указанной лубочной сказки на устную традицию [см.: Лызлова 2015].

В лубочной литературе публиковались не только обработанные фольклорные сюжеты, но также переводные рыцарские романы и повести. Подобные тексты были записаны от Ф. С. Смирнова и включены Г. Е. Власьевым в сборник: таковы сказки «Бова-королевич», «Франциль Венциян», «Марцимерис» и «Английский милорд Георг». В примечаниях к этим произведениям составителем сообщается: «сказка является изложением какой-то книжной истории», «пересказ лубочной книжки», «изложение лубочной книжки» [ВС 1941, $254,256]$. К примеру, «Сказка о славном и сильном богатыре Бове королевиче и о прекрасной супруге его Дружневне» известна в рукописных редакциях, печатные издания выходили с 60-х годов XVIII в; «Повесть о приключениях английского милорда Георга и бранденбургской маркграфини Фридерики-Луизы» «...в XVIII в. распространялась в рукописи под названием "Повесть об английском милорде Гереоне...”, а в в 1782 г. была впервые издана (в Петербурге) в обработке Матвея Комарова» [Лубочная книга 1990, 388]; «История о храбром рыцаре Францыле Венциане и о прекрасной королеве Ренцывене» была впервые опубликована в 1780-х годах и неоднократно выходила впоследствии в лубочных изданиях [Лубочная книга 1990, 391].

В некоторых текстах, записанных от Ф. С. Смирнова, заметно влияние авторских произведений. Так, например, сказка «Солдат Антипка» практически дословно воспроизводит «Огниво» Х. К. Андерсена. По словам В. Е. Добровольской, «...этот сюжет довольно популярен в устной традиции. Однако если мы обратимся к публикациям сказок, то увидим, что он почти не встречается в сборниках $<\ldots>$. Текстов «Огниво» на данный момент 
опубликовано три» [Добровольская 2017, 45]. То есть вариант Смирнова дополняет эти сведения. В нем солдат, возвращаясь на родину после службы в армии, встречает Бабу Ягу - костяную ногу, которая предлагает ему заработать денег, если он выполнит ее просьбу:

\begin{tabular}{|l|l|}
\hline — Видишь вон то & - Лезь на эту леси- \\
старое дерево? - & ну! Там есть дупло; \\
сказала ведьма, по- & завяжи веревку \\
казывая на дерево, & вокруг себя, и я тебя \\
которое стояло & отпущу туда. Там \\
неподалеку. & увидишь длинный \\
- Оно внутри & коридор, сотни све- \\
пустое. Влезь наверх, & чей горят [ВС 1941, \\
там будет дупло, ты & 166]. \\
и спустись в него, в & \\
самый низ! А перед & \\
тем я обвяжу тебя & \\
веревкой вокруг по- & \\
яса, ты мне крикни, и \\
я тебя вытащу. <...>. \\
Знай, что когда ты \\
доберешься до само- \\
го низа, то увидишь \\
большой подземный \\
ход; в нем горит \\
больше сотни ламп, \\
и там совсем светло \\
[Андресен 1977, \\
29-30]. \\
\hline
\end{tabular}

Внутри подземелья в трех комнатах сидят собаки, которых можно усмирить с помощью полученного от ведьмы в сказке Андерсена клетчатого передника, а в сказке, записанной от Смирнова, - фартука.

\begin{tabular}{|c|c|}
\hline $\begin{array}{l}\text { «Войди в первую } \\
\text { комнату; посреди } \\
\text { комнаты увидишь } \\
\text { большой сундук, а на } \\
\text { нем собаку: глаза у } \\
\text { нее, словно чайные } \\
\text { чашки! <...> В этом } \\
\text { сундуке одни медя- } \\
\text { ки; захочешь сере- } \\
\text { бра — иди в комнату } \\
\text { рядом: там сидит } \\
\text { собака с глазами, как } \\
\text { мельничные колеса! } \\
\text { <...> А захочешь, так } \\
\text { достанешь и золота, } \\
\text { сколько можешь } \\
\text { унести: пойди только } \\
\text { в третью комнату. } \\
\text { У собаки, сидящей } \\
\text { там на деревянном } \\
\text { сундуке, глаза - } \\
\text { каждый с Круглую } \\
\text { башню. Вот это } \\
\text { собака!» [Андерсен } \\
\text { 1977, зо]. }\end{array}$ & $\begin{array}{l}\text { «ройдешь по } \\
\text { коридору, в первую } \\
\text { дверь зайди, там } \\
\text { сидит собака на } \\
\text { сундуке, - глаза с } \\
\text { чайное блюдце. <...> } \\
\text { Иди дальше, зайди } \\
\text { во вторую дверь, } \\
\text { там собака сидит на } \\
\text { сундуке, — глаза с } \\
\text { мельничное колесо. } \\
<. . .>\text { Там зайди в } \\
\text { третью дверь. Там } \\
\text { сидит собака на } \\
\text { сундуке громадного } \\
\text { росту, глазища с } \\
\text { таможенную башню } \\
<. . .>\text { [ВС 1941, 166]. }\end{array}$ \\
\hline
\end{tabular}

В том и в другом тексте ведьма / Баба Яга просит солдата принести ей огниво. Когда она хочет забрать его себе, солдат отрубает ей голову.

В сказке Смирнова сохранены детали, идущие от литературного источника (три собаки, встреченные героем в подземелье; огниво, при трении о которое появляются собаки и выполняют все задания солдата; женитьба на принцессе / царевне). Своеобразие заключается в том, что герой получает у вепсского сказочника имя - Антипка (что отражено в названии), а вместо ведьмы фигурирует Баба Яга.

В репертуаре Смирнова представлена еще одна сказка, связанная с творчеством Х. К. Андерсена. Называется она «Силуам», по имени двух братьев-персонажей, в ней «некоторые детали особенно близки к сказке Андерсена "Большой Клаус и маленький Клаус" (одинаковые имена бедняка и богача, восклицание: “Эх, моя шестерочка!” и пр.)» [ВНС 1941, 257]. 


\begin{tabular}{|l|l|}
\hline В одной деревне & В одной деревне \\
жили два человека; & было два брата: один \\
обоих звали Клауса- & - большой Силуам, \\
ми, но у одного было & другой — малень- \\
четыре лошади, а у & кий Силуам. Один \\
другого только одна; & имел пять лошадей, \\
так вот, чтобы раз- & другой - одну. \\
личить их, и стали & Вот, когда рабочее \\
звать того, у кото- & время, богатый \\
рого было четыре & берет последнюю \\
лошади, Большой & лошадь и работника, \\
Клаус, а того, у кото- & а когда праздничный \\
рого одна, Малень- & день, дает всех своих \\
кий Клаус. <...> & лошадей ему. \\
Всю неделю, как & В воскресный день \\
есть, должен был & Силуам маленький \\
Маленький Каллус & пашет на шестерке: \\
пахать на своей & - Ну, пошла, моя \\
лошади поле Боль- & шестерочка! [ВНС \\
шого Клауса. Зато тот & 1941, 204]. \\
давал ему всех своих \\
четырех, но только \\
раз в неделю, по вос- \\
кресеньям. <..> Ма- \\
ленький Клаус <...> \\
был очень доволен, \\
пощелкивал кнутом \\
и покрикивал: \\
- Эх вы, мои лоша- & \\
душки! [Андерсен & \\
Х. К.1977, з7]. & \\
& \\
& \\
&
\end{tabular}

Дальнейшие события развиваются в соответствии с сюжетным типом СУС 1535 Дорогая кожа: богач убивает единственную лошадь бедняка, и тот отправляется из дома, прихватив с собой шкуру; остановившись на ночлег, случайно выясняет, что хозяйка обманывает своего мужа, приглашая в его отсутствие в гости церковного старосту (у Андерсена пономаря); раскрыв секреты неверной жены, получает деньги и, вернувшись домой, говорит богачу, что продал лошадиную шкуру; брат убивает всех своих лошадей и, оставшись ни с чем, хочет утопить маленького Силуама, но тот сажает вместо себя в мешок старика, желающего оказаться в раю в обмен на стадо коров и быков; большой Силуам верит, что стадо добыто под водой, и позволяет себя утопить: «-Ай, брат, будь добр и брось меня в воду, и там дадут мне стадо коров» [BC 1941, 206]. По замечанию составителя сборника Г. Е. Власьева, «...Смирнов излагает сказку несколько упрощенно (нередко сюда включаются еще эпизоды, как старший брат, обманутый младшим, убивает свою жену и пр.)» [Там же, 257]. Более развернутый вариант представлен как раз у Х. К. Андерсена.

В записанном от Смирнова тексте «Гостиный двор» наблюдаются переклички с начальным эпизодом «Сказки о Царе Салтане» и поэмы «Руслан и Людмила» А. С. Пушкина:

«Вот жил царь, и ему дано было выбрать невесту. Он по вечерам подслушивал под окном, кто, где, что говорит.

Было три девицы-сестрицы, и пряли поздно вечерком и разговаривали между собой. Одна была ткачиха, а другая - повариха.

- Если бы Иван-царевич взял бы меня замуж, я бы приготовила пир на весь мир, - говорит повариха.

Говорит ткачиха:

- Если бы взял меня Иван-царевич замуж, я бы наткала полотна, что хватило бы на все войско.

А младшая сестра, третья, говорит:

- Если бы меня взял Иван-царевич замуж, я для батюшки-царя родила бы богатыря» [ВС 1941, 39].

В этой сказке царица в отсутствие мужа родила «двойчат - двух мальчиков». Одного из них похищает злой дух, а второго запечатывают с матерью в бочке и бросают в море. Сюжет заканчивается встречей братьев и единением всей семьи. В этом же тексте фигурирует кот, чрезвычайно напоминающий соответствующий образ в «Прологе» к поэме А. С. Пушкина «Руслан и Людмила»: «Потом есть серой кот: в сосну стает - песню поет, чудные песни, с сосны опускается - сказки рассказывает, просто прелесть!» [ВС 1941, 41].

Наконец, в репертуаре Ф. С. Смирнова представлена сказка «Конек-Горбунок», которая имеет своеобразную историю. В 1834 г. П. П. Ершовым было написано стихотворное произведение с таким названием. В конце 1840-х гг. сказка попала в лубочные издания и имела несколько редакций, что показывает исследование, проведенное К. Е. Кореповой [Корепова 2012, 283-337]. Как отмечает исследовательница, «...начиная с 60-х годов XIX века стали выходить переделки "КонькаГорбунка" Ершова в форме пересказа другими стихами или прозой почти без отступления от сюжетной линии источника, но с пропуском отдельных описательных 
фрагментов» [Корепова 2012, 308]. В примечании к тексту Смирнова составителем Г. Е. Власьевым отмечается связь со сказкой Ершова: «...показательны продажа коней, встреча с китом, драка ерша с карасем».

Итак, многие сказки, записанные от данного вепса, по своему происхождению восходят к лубочной литературе и к авторским произведениям. Сборник, подготовленный Власьевым, с одной стороны, демонстрировал незаурядные способности одного из представителей вепсов, обладавшего большим репертуаром, a с другой стороны, свидетельствовал о тесном взаимодействии соседствующих вепсской и русской сказочных традиций. В материалах собирателей отмечается, что Смирнов одинаково хорошо рассказывал сказки и по-русски, и по-вепсски. Он был грамотным человеком, поэтому его тексты отличались большим объемом, т. е. он был исполнителем так называемых долгих сказок. Как уже говорилось выше, практически все его тексты были записаны на русском языке. К сожалению, теперь мы можем только предполагать, почему так произошло. Между тем собиратели Г. Е. Власьев и П. Карпов, фиксировавшие его сказки, записывали в 1937 г. произведения данного жанра от

\section{Источники и материалы}

Андерсен 1977 - Андерсен Х. К. Сказки и истории: В 2 т. Т. 1. Л., 1977.

ВНС 1996 - Вепсские народные сказки. Vepsän rahvhan sarnad / Сост. Н. Ф. Онегина, М. И. Зайцева. Петрозаводск, 1996.

ВС 1941 - Вепсские сказки / Зап. текстов, предисл. и прим. Г. Власьева. Петрозаводск, 1941.

Лубочная книга 1990 - Лубочная книга / подгот. текста, сост., вступ. ст., коммент. А. Рейтблата. М., 1990.

СУС 1979 - Сравнительный указатель сюжетов. Восточнославянская сказка / Сост. Л. Г. Бараг, И. П. Березовский, К. П. Кабашников, Н. В. Новиков. Л., 1979.

Тимофеев 2001 - Сказки русские, содержащие в себе 10 различных сказок. Собраны и записаны П. Тимофеевым // Лекарство от задумчивости. Русская сказка в изданиях 80-х годов 18 века. СПб., 2001. С. 229-378.

\section{Исследования}

Добровольская 2017 - Добровольская B. E. Литературные произведения в фольклорной традиции: литературные предпочтения других вепсов в Прионежье на их родном языке; эти записи, конечно, по размеру уступают сказкам Смирнова. Попутно отметим, что, к примеру, в коми сказочной традиции также происходило усвоение русской лубочной литературы и проникновение ее в виде устных вариантов в народную среду в процессе вторичной фольклоризации. Между тем подобные сказки не отвергаются исследователями как чужеродные; их изучением занимается, в частности, Н. С. Коровина, которая отмечает, что коми сказочный фонд значительно пополнился благодаря русским лубочным сказкам [Коровина 2013, 56-104]. Что касается творчества Смирнова, то его, как нам представляется, правомерно относить к двум сказочным традициям (русской и вепсской).

Итак, Ф. С. Смирнов принадлежит к числу носителей фольклора, которые способствовали тому, что сказка, напечатанная на страницах книги, продолжила свое существование в устном бытовании. Его репертуар включает в себя сюжеты, распространенные прежде всего в русской сказочной традиции, и наглядно демонстрирует явление литературного влияния на фольклорную традицию, которое не всегда учитывается.

- 2017. Фольклор, литературы и языки народов европейской части России: формы, модели, механизмы взаимодействия. Сыктывкар, 2017. C. $44-48$.

Корепова 2012 - Корепова К. Е. Русская лубочная сказка. М., 2012.

Коровина 2013 - Коровина Н. С. Типология взаимодействия коми и русских волшебных сказок (сюжетный состав, художественно-стилевая структура). Сыктывкар, 2013.

Лызлова 2009 - Льъзлова А. С. Вепсский сказочник Ф. С. Смирнов // Ученые записки Петрозаводского государственного университета. 2009. № 6 (100). С. 65-69.

Лызлова 2011 - Лызлова А. С. Редкие издания в личном архиве Р. П. Лонина: Сб. «Вепсские сказки» // Вепсы и их культурное наследие: связь времен (памяти Р. П. Лонина). Петрозаводск, 2011. С. 100-107.

Лызлова 2017 - Лыззлова А. С. «Сказка о Светлане Прекрасной» из репертуара И. Ф. Ковалева (д. Шадрино Нижегородской области) в контексте общерусской сказочной традиции // Фольклор Большой Волги. М., 2017. C. $189-201$.

(c) А. С. Лызлова, 2019 сказочников // Филологические исследования 


\section{СВЕДЕНИЯ ОБ АВТОРЕ}

Лызлова А. С. https://orcid.org/0000-0002-0634-706X

Кандидат филологических наук, научный сотрудник Института языка, литературы и истории Карельского научного центра РАН: Российская Федерация, Республика Карелия, 185910, г. Петрозаводск, ул. Пушкинская, д. 11; тел.: +7(8142) 78-18-86;

e-mail: alyzlova@mail.ru 


\section{LITERARY SOURCES OF TALES OF VEPS BY F. S. SMIRNOV}

\section{ANASTASIA S. LYZLOVA}

(Institute of Linguistics, Literature and History, Karelian Research Center, Russian Academy of Science: 11, Pushkinskaya str., Petrozavodsk, 185910, Republic of Karelia, Russian Federation)

Summary. The article is devoted to the repertoire of the Vepsian taleteller Filipp Semenovich Smirnov (1863-1938), whose texts were recorded in 1935-1936 mainly in Russian and later made up a separate archival collection of the Russian-language folklore fund of the Scientific Archives of the Karelian Research Center of the Russian Academy of Sciences. Most of the tales were included in the collection "Vepsian tales", published in 1941 in Petrozavodsk and compiled by G. E. Vlasyev. F. S. Smirnov, being a literate person, replenished his repertoire with various literary works: many of the texts recorded from him go back to the tales of A. S. Pushkin, P. P. Ershov, Kh. K. Andersen, cheap popular (luboc) fairy tales, translated knightly novels and stories of the 18th century.

Key words: Vepsian taleteller, F. S. Smirnov, collection "Vepsian tales", literary sources, cheap popular (luboc) fairy tales.

Acknowledgements. The article was prepared in the framework of the state task of Karnts RAS "Folklore traditions and handwritten books of the European North: source studies, textual studies, poetics, ethnographic context", state registration number AAAA-A18-118030190094-6.

Received: July 23, 2019.

Date of publication: December 10, 2019.

For citation: Lyzlova A.S. Literary Sources of Tales of Veps F. S. Smirnov (1863-1938). Traditional culture. 2019. Vol. 20. No. 5. Pp. 196-205. In Russian.

DOI: $10.26158 /$ TK.2019.20.5.017

\section{References}

Dobrovol'skaya V. E. (2017) Literaturnyye proizvedeniya $\mathrm{v}$ fol'klornoy traditsii: literaturnyye predpochteniya skazochnikov [Literary works in folklore tradition: literary preferences of storytellers]. In: Filologicheskiye issledovaniya 2017. Fol'klor, literatury i yazyki narodov yevropeyskoy chasti Rossii: formy, modeli, mekhanizmy vzaimodeystviya [Philologicalstudies 2017. Folklore, literature and languages of the peoples of the European part of Russia: forms, models, mechanisms of interaction]. Syktyvkar. Pp. 44-48. In Russian.

Korepova K. E. (2012) Russkaya lubochnaya skazka [Russian Luboc Fairy Tale]. Moscow. In Russian.

Korovina N. S. (2013) Tipologiya vzaimodeystviya komi i russkikh volshebnykh skazok (syuzhetnyy sostav, khudozhestvenno-stilevaya struktura) [Typology of the interaction of Komi and Russian fairy tales (plot composition, artistic style structure)]. Syktyvkar. In Russian.

Lyzlova A. S. (2009) Vepsskiy skazochnik F. S. Smirnov [The Vepsian taleteller F. S. Smirnov].
Uchyonye zapiski Petrozavodskogo Gosudarstvennogo Universiteta [Proceedings of Petrozavodsk State University]. No. 6 (100). Pp. 65-69. In Russian.

Lyzlova A. S. (2011) Redkie izdaniya v lichnom archive R. P. Lonina: sbornik "Vepsskie skazki"[Rare editions from personal archive by R. P. Lonin: the «Vepsian tales»]. In: Vepsy i ikh kul'turnoe nasledie: svyaz' vremen (pamyati R. P. Lonina) [Vepsians and their cultural heritage: the connection to time (by memory of R. P. Lonin). Petrozavodsk. Pp. 100-107. In Russian.

Lyzlova A. S. (2017) «Skazka o Svetlane Prekrasnoy» iz repertuara I.F. Kovaleva (d. Shadrino Nizhegorodskoy oblasti) v kontekste obshcherusskoy skazochnoy traditsii ["The Tale of Svetlana the Beautiful" from the repertoire of I.F. Kovalev (d. Shadrino, Nizhny Novgorod Region) in the context of the All-Russian fairy tradition]. In: Fol'klor Bol'shoy Volgi [Folklore of the Great Volga]. Moscow. Pp. 189-201. In Russian.

(C) A. S. Lyzlova, 2019 


\section{ABOUT THE AUTHOR}

Anastasia S. Lyzlova https://orcid.org/0000-0002-0634-706X

E-mail: alyzlova@mail.ru

Tel.: +7(8142)78-18-86

11, Pushkinskaya str., Petrozavodsk, 185910, Republic of Karelia, Russian Federation $\mathrm{PhD}$ in Philology, Researcher, Institute of Linguistics, Literature and History, Karelian Research Center, Russian Academy of Science 